INVESTIGACIONES

de HISTORIA ECONÓMICA

2006, otoño, número 6. Pp. 73 a 104

\title{
Reformas arancelarias y comercio exterior de trigo en España: el fin de la prohibición de importar trigo (1849-1869)
}

\author{
Tariff reforms and foreign wheat trade in Spain: \\ the end of the ban to import wheat (1849-1869)
}

\author{
ENRIQUE MONTAÑÉS PRIMICIA \\ Universidad de Cádiz
}

\begin{abstract}
RESUMEN
En este trabajo se analizan algunas de las realidades que favorecieron el mantenimiento de la prohibición de importar trigo en España entre 1849 y 1869. A través del contraste de las series de precios del trigo con la información suministrada por las actuaciones gubernamentales, las discusiones parlamentarias y los documentos redactados por los diferentes grupos de presión, se pretende precisar la función del prohibicionismo en el comercio exterior del trigo. Se concluye que las ciudades del litoral podían importar trigo tan barato como el del interior. No obstante, dado el crecimiento de

los precios del trigo desde 1853, existió un margen para sustituir la prohibición de importar trigo por el establecimiento de derechos arancelarios protectores. Sin embargo, la existencia de un bloqueo político constante impidió la realización de esa reforma arancelaria. Sólo cuando se produjo un cambio de régimen la prohibición pudo desaparecer.
\end{abstract}

PALABRAS CLAVE: Comercio del trigo, Reforma arancelaria, Agentes económicos, España, Siglo XIX

Códigos JEL: N33, N43, N53, N73, Q13, Q18

\section{ABSTRACT}

This paper analyses some factors that supported the Spanish ban to import wheat between 1849 and 1869 . Through the study of the parliamentarian debates, the government documents, informs of the economic agents, and the series of wheat prices, the paper tries to fix the function of the ban to import wheat in the liberal regime. It is concluded that coastal cities could get foreign wheat as cheap as Spanish wheat. However, the ban could have been replaced with customs duties due to the increase of the wheat prices in the international markets. Nevertheless, the political obstacles subsisted and the reform failed. When the political regimen changed, the ban was repealed.

KEYWORDS: Wheat trade, Reform of the customs duties, Economic agents, Spain, 19th Century

JEL Codes: N33, N43, N53, N73, Q13, Q18 


\section{Introducción 1}

$\mathrm{E}$ 1 objetivo del presente trabajo es analizar algunas de los factores que favorecieron el mantenimiento de la prohibición de importar trigo y que se han replanteado en el debate actualmente entablado². En primer lugar, se pretende estudiar si realmente las ciudades del litoral español tenían la posibilidad de importar trigo foráneo más barato que el procedente del interior peninsular. Para ello, es preciso contrastar los datos y argumentos ofrecidos por los productores y los posibles importadores con la evolución de los precios en los mercados del litoral y del interior, así como de los mercados de otras zonas suministradoras entre 1849 y 1869.

En segundo término, a partir de las conclusiones obtenidas de dicho interrogante, se abordará el carácter del prohibicionismo en el comercio exterior de trigo. Se quiere delimitar hasta qué punto era un instrumento para estimular la producción nacional y favorecer la conquista del mercado interior o si, por el contrario, era un mecanismo privilegiado de los propietarios y cultivadores para capturar rentas y beneficios extraordinarios. También, se desea determinar si las tensiones y conflictos generados por la legislación prohibicionista y su aplicación práctica impulsaron las reformas arancelarias. En consecuencia, se aborda de qué manera se contempló el comercio exterior de trigo en las sucesivas reformas arancelarias, tanto en las que se realizaron efectivamente como en los proyectos fallidos.

Mediante el contraste de las series de precios del trigo con la información suministrada por las actuaciones gubernamentales, las discusiones parlamentarias y los documentos redactados por los diversos grupos de presión, se pretende precisar la función del prohibicionismo en el comercio exterior de trigo. A la par, se estudia si las alternativas propuestas por los partidarios de una mayor liberalización, sustituyendo la prohibición por aranceles, habrían supuesto una grave pérdida del mercado para la producción cerealista española o si, por el contrario, sus efectos habrían sido mucho más limitados, dados los cambios en los mercados internacionales de trigo.

[Fecha de recepción del original, noviembre de 2005. Versión definitiva, abril de 2006]

1 Este trabajo forma parte del proyecto de investigación "Las Cortes de Cádiz y el primer liberalismo en Andalucía", Proyecto de Excelencia del Plan Andaluz de Investigación (PAI-05-HUM-00549). Agradezco las observaciones de los evaluadores anónimos de Investigaciones de Historia Económica porque me han incitado a mejorarlo. Asimismo, me han sido de gran utilidad algunos comentarios de Domingo Gallego, James Simpson y Diego Caro Cancela.

2 Debate suscitado por la valoración del desarrollo agrario español expuesta, en 2001, por los autores de El pozo de todos los males, que fue enriquecida por los comentarios de Enrique Llopis, Jordi Palafox, Pere Pascual y Carles Sudrià, y James Simpson, publicados en el número 28 de Historia Agraria. Más recientemente, destacan las aportaciones de Gallego (2004) y (2005). 
La existencia, o no, de un margen para sustituir la prohibición por un arancel nos permite establecer algunas conclusiones respecto de los obstáculos políticos al cambio arancelario. La falta de modificaciones entre 1849 y 1869 sugiere la existencia de un bloqueo político vinculado a la naturaleza del régimen isabelino, puesto que sólo el nuevo régimen instaurado en 1868 fue capaz de suprimir la prohibición.

De acuerdo con los objetivos propuestos, el trabajo aborda inicialmente la reforma arancelaria de 1849, analizándose sus objetivos, las alteraciones propuestas, los debates y las posiciones políticas suscitadas. Posteriormente, se estudian los cambios en el comercio internacional de trigo y sus repercusiones sobre los mercados españoles, entre las que destaca la crisis de subsistencias de 1856. La profundidad de ésta, que provocó un largo período de carestía y hambre, impulsó un amplio debate, a finales de 1858, sobre la conveniencia de eliminar o mantener la prohibición de importar trigo establecida desde 1820. Ello generó una amplia movilización de los diferentes grupos de presión que pretendieron incidir sobre la decisión gubernamental. Se analizan las posturas de los favorables a la liberalización del comercio de cereales y de los partidarios de la prohibición, así como el resultado final del proceso, que significó el restablecimiento de la prohibición de importar trigo.

Seguidamente, se estudia el período 1858-1869, tratando de contemplar la relación existente entre la trayectoria de los mercados internacionales, el mantenimiento de la prohibición, la evolución de los mercados españoles y el desarrollo de una nueva crisis de subsistencias en 1866. La estrecha conexión entre este nuevo lapso de carestía y hambre, y el cambio político de 1868 ha sido suficientemente resaltada ${ }^{3}$. Pero la forma en que se abordó la cuestión de los cereales por el nuevo régimen no se ha analizado con profundidad. Por ello, el trabajo se cierra con el análisis de la reforma arancelaria de 1869, que supuso la definitiva eliminación del prohibicionismo en el comercio de trigo.

\section{La reforma arancelaria de $\mathbf{1 8 4 9}$}

En un trabajo anterior ${ }^{4}$, he analizado el nacimiento de la prohibición de importar trigo en el contexto político y económico del Trienio liberal. El estudio sistemático de las actuaciones parlamentarias en torno al comercio exterior de trigo confirma el carácter central de la disposición prohibicionista en la política comercial del régimen 
liberal. Se adoptó como recurso urgente para favorecer la integración de los mercados peninsulares, como medio para frenar la caída de los precios y como instrumento para ampliar el apoyo político al naciente régimen liberal. Parece evidente que estos objetivos se alcanzaron en mayor o menor medida: se mejoró la integración de los mercados del interior con la periferia litoral, los precios se recuperaron, y la superficie cultivada y la producción se incrementaron ${ }^{5}$. Pero los altos precios reguladores establecidos para autorizar la importación, aparte de dispensar una defensa eficaz frente a la competencia exterior, también potenciaron el tradicional juego especulativo en el transcurso del año agrícola, agudizando la fluctuación de los precios durante los años normales en el litoral y durante los años excepcionales en el interior.

La carestía y la escasez originadas por la crisis de subsistencias de 1847 provocaron un destacado debate político sobre la conveniencia de la prohibición. La subida de precios habida en 1846 en los mercados internacionales estimuló el crecimiento de la exportación. Pero la venta de trigo al exterior, al coincidir con una nueva cosecha escasa, dio lugar a graves problemas de abastecimiento en algunas ciudades del litoral en la primavera de 1847, lo que causó una notable alza de los precios. Esta situación se generó debido a las disposiciones que recogía el decreto de 1834, que regulaba el comercio exterior de trigo. Recordemos que este decreto, a la vez que establecía la libertad de exportación, prohibía la importación de trigo salvo en aquellos períodos en que se alcanzaran unos determinados precios en las ciudades del litoral ${ }^{6}$.

La falta de sincronía entre la libertad de exportación y la de importación abonaba la especulación en los años excepcionales y propiciaba unos beneficios extraordinarios. Las movilizaciones populares contra la carestía y contra las exportaciones de trigo obligaron al gobierno a autorizar las importaciones y a prohibir temporalmente las exportaciones. Éste, incluso, presentó un proyecto para regularlas en el futuro y promovió el estudio del problema por parte de una comisión parlamentaria. Dicha comisión, no obstante, concluyó que el prohibicionismo seguía siendo preciso para mantener los mercados del litoral. Aceptada esta tesis sin discusión, la mayoría parlamentaria, moderada, se negó a aplicar precios reguladores a la exportación de trigo. Una vez que descendió la tensión social, el gobierno retiró las medidas que limitaban las exportaciones y abandonó la idea de modificar la normativa de 1834, ante la abierta oposición de los diputados que conformaban su propia mayoría.

García Sanz (1985).

Real decreto declarando libre la venta de cereales, sus harinas y toda clase de granos y semillas, 29 de enero de 1834. En este decreto se fijaba un precio regulador para autorizar las importaciones de trigo (70 reales por fanega) y de harina (110 reales por quintal). 
El debate suscitado y sus resultados muestran hasta qué punto el régimen liberal, sostenido por un sufragio muy restringido, privilegiaba los intereses de los propietarios y cultivadores. La preocupación constante de estos últimos por mantener altos los precios del trigo implicaba el control absoluto de los mercados del litoral. Siendo éste el objetivo inicial de 1820, logrado durante buena parte del período, no se quiso renunciar a lo obtenido ni siquiera en los años de crisis de subsistencias.

La admisión permanente de trigos extranjeros, con los correspondientes aranceles, ¿hubiera cuestionado el predominio de los trigos del interior? Los datos aportados por los comerciantes de Cádiz hacia 1847 indican que la competencia del trigo importado era posible en ciertos momentos del año agrícola, cuando los precios superaban los 50 reales por fanega en las urbes del litoral. El problema era que los propietarios y los labradores aspiraban a moverse siempre por encima de esos precios para alcanzar unos beneficios "protegidos". La principal ciudad importadora del litoral, Barcelona, asimiló el prohibicionismo porque aseguró el mercado para sus manufacturas y su balanza comercial con el resto de España pudo alcanzar el superávit ${ }^{7}$.

En otras ciudades del litoral, como Cádiz, más volcadas hacia el comercio exterior y con dificultades para encontrar alternativas que compensaran el creciente déficit con el interior, algunos grupos de comerciantes siguieron defendiendo la libre importación como mecanismo regulador del mercado, negando que dicha medida fuera una amenaza para el trigo del interior. Esta postura no encontró ningún apoyo político, ni siquiera se planteó como posibilidad. Desde el restablecimiento del régimen liberal en 1820, los sucesivos gobiernos y mayorías parlamentarias defendieron unos precios altos para el trigo como compensación por la estructura fiscal existente. El hecho de que la mayor parte de la presión fiscal descansara sobre las actividades agrarias ${ }^{8}$, eliminaba el margen de actuación para modificar el prohibicionismo. Solamente con una reducción de la presión fiscal sobre el sector agrario era imaginable la posibilidad de superar el prohibicionismo. No parece que ningún gobierno de la época contemplara esta alternativa, porque no era probable que un incremento de los ingresos fiscales mediante la imposición de aranceles compensara dicha disminución.

Ante esa realidad política, el proyecto de reforma arancelaria de 1849, presentado por el ministro de Hacienda Alejandro Mon, dejó al margen, una vez más, la regulación del comercio exterior de trigo y se centró en el otro capítulo que quedaba pendiente desde 1841: los algodones. Como han señalado Comín y Vallejo ${ }^{9}$, los objetivos

\footnotetext{
Fradera (1987), p. 240.

Vallejo (2001), p. 96.

Comín y Vallejo (2002), p. 425.
} 
de esta reforma eran sobre todo fiscales. Mon buscaba ampliar el poder recaudatorio de los aranceles, reduciendo las posibilidades del contrabando, para completar la reforma fiscal de 1845 y alcanzar el ansiado equilibrio presupuestario. De esta manera, se podría plantear una cierta reducción de la presión fiscal sobre el sector agrario. En consecuencia, en el proyecto que presentó la Comisión para su discusión en las Cortes, se contempló la reducción de las prohibiciones y su sustitución por derechos arancelarios claramente protectores.

Entre las prohibiciones eliminadas se incluía la tocante a los tejidos de algodón, aunque sólo de forma parcial. Aparentemente era una novedad muy destacada respecto al sistema prohibicionista instaurado en 1820, y levantó una fuerte oposición en los grupos relacionados con la industria textil catalana. Aunque en el dictamen ${ }^{10}$ de la Comisión se decía que la prohibición se mantenía para aquellos productos de algodón que realmente tenían una producción significativa en España y que, por tanto, en nada se vería afectada la industria catalana, la oposición de los diputados catalanes y sus aliados fue frontal. Éstos se resistían a cualquier liberalización que, dado el funcionamiento del sistema de aduanas, incrementase el contrabando y perjudicase gravemente a la industria nacional. Su argumentación seguía siendo muy similar a la de 1820 ó 1841. Defendían la más absoluta prohibición como método para desarrollar una industria naciente y como instrumento necesario para favorecer la integración de los mercados regionales. Insistían en que la prohibición de los algodones iba estrechamente unida a la de los cereales, ya que, como Cataluña era un importante mercado para los productos agrarios del interior, éste debía de seguir siendo el mercado natural de los productos textiles catalanes.

En el citado trabajo de Comín y Vallejo ${ }^{11}$, se analiza con detalle el trámite legislativo que desembocó en la aprobación parlamentaria de la reforma. Parece evidente que la coalición entre los intereses cerealistas y algodoneros que había impulsado el sistema prohibicionista en 1820 dejó de actuar de forma absolutamente cohesionada. Los diputados catalanes se quedaron prácticamente aislados en la defensa del prohibicionismo, a pesar de sus invocaciones a la solidaridad dirigidas hacia los productores cerealistas. Éste es el aspecto que me interesa resaltar. La cuestión de los cereales terminó por aparecer en el debate de la reforma arancelaria, aunque no estaba planteada ninguna modificación en su regulación.

Nuevamente, como en 1841, el diputado Madoz fue uno de los más destacados en la defensa del prohibicionismo. Fue él quien advirtió, una vez más, de la estrecha

\footnotetext{
10 Dictamen de la comisión con las aclaraciones hechas últimamente por la misma sobre el proyecto de ley para la reforma de los aranceles vigentes. Diario de Sesiones de Cortes-Congreso de los Diputados (DSC-CD, en adelante), $13 / 06 / 1849$, p. 2.573 .

11 Comín y Vallejo (2002), pp. 428-465.
} 
relación entre los intereses agrícolas e industriales y de la necesidad de seguir manteniendo el marco prohibitivo en ambos sectores. En su opinión, la reforma arancelaria provocaría la llegada de productos textiles británicos sin que los productos agrícolas españoles (trigos, vinos, aceites) obtuvieran un incremento de sus ventas en los mercados exteriores. Ni los trigos españoles eran competitivos en el mercado británico, ni los vinos españoles lograrían una rebaja en los aranceles británicos, ni la demanda de aceite aumentaría ${ }^{12}$.

Si ese discurso, que apelaba a la defensa del mercado interior frente a la competencia exterior, había sido efectivo en anteriores ocasiones, en 1849 ya no suscitaba un apoyo incondicional. Primero, porque la producción de la industria textil seguía quedando protegida, como había indicado la Comisión. Segundo, porque el prohibicionismo ya no estimulaba el crecimiento económico, ni era adecuado para incrementar los ingresos fiscales del Estado. Y, tercero, porque la abolición de las leyes de cereales en Gran Bretaña en 1846 y las condiciones de los mercados internacionales en 1846 y 1847, estaban generando nuevas expectativas entre los productores españoles de trigo. Las significativas exportaciones trigueras de 1846, que incidieron en la carestía de 1847, hicieron pensar en la posibilidad de lograr que el trigo también fuera un producto de exportación, como el vino o el aceite.

Un diputado tan representativo de la mayoría moderada como García Barzanallana, se encargó de disipar los temores esparcidos por Madoz. Negó rotundamente que la supresión de la normativa prohibicionista condujera irremediablemente a la ruina de la agricultura y la industria nacionales ${ }^{13}$. Es más, defendió que si se eliminaba la prohibición y se establecía un derecho de entrada que garantizase una "ganancia razonable" a los productores, la agricultura española no se resentiría. Llama mucho la atención que, en esta ocasión, García Barzanallana ${ }^{14}$ se alejara tan nítidamente de las tesis oficiales recogidas en la Información de 1847 y de la propia mayoría moderada que, en plena crisis de subsistencias de 1847, se negó a reformar la legislación prohibicionista. Es posible que quisiera aprovechar las expectativas exportadoras abiertas para fraccionar la tradicional coalición de los prohibicionistas, en un momento en que los cereales habían quedado fuera de la reforma arancelaria.

Esa marginación de los cereales de la reforma arancelaria se justificaba por la inestable situación del comercio de granos tras las alteraciones de 1846 y 1847. En esas circunstancias, no era aconsejable ningún cambio en la legislación. Pero García Barzanallana defendía que no se debía amenazar con la ruina de la agricultura para

12 DSC-CD, 13/06/1849, p. 2.555.

13 "...todo ese miedo que se quiere explotar diciendo a los agricultores que arruinada la industria de Cataluña y faltos de consumidores sus granos el precio de éstos disminuiría, son una ilusión". DSC-CD, 14/06/1849, p. 2.588.

$14 \quad$ DSC-CD, 14/06/1849, p. 2588. 
defender el prohibicionismo respecto de los productos industriales. Negaba, asimismo, que la reforma de los aranceles estuviera pensada para favorecer a Inglaterra, si bien reconocía que dicho país era el principal mercado de los productos españoles ${ }^{15}$.

El diputado andaluz Lafuente Alcántara, que se había distinguido durante la crisis de 1847 en la defensa de la exportación de trigo, aún expresó un punto de vista más radical. Reclamó la inclusión de los granos en la reforma arancelaria, a fin de garantizar la libertad de exportación que, entendía, se hallaba limitada en aquel momento $^{16}$. Insistía en que el desarrollo agrícola experimentado en los últimos años necesitaba un marco legislativo menos restrictivo ${ }^{17}$. Pero no todo el mundo era optimista respecto de las posibilidades de la producción cerealista. El diputado Seijas, que había sido ministro en 1847 y había avalado la prohibición de exportar trigo durante la crisis de subsistencias, entendía que los excedentes trigueros en un año normal eran más bien modestos y que, por tanto, no podía abandonarse la protección a la agricultura ${ }^{18}$. Pese a todo, también era partidario de ir eliminando las prohibiciones.

También se mostró favorable a una mayor liberalización el portavoz más señalado de los grupos exportadores andaluces, el diputado por Sevilla Sánchez Silva. Aunque presentó una enmienda, que no fue aprobada, para eliminar todas las prohibiciones que afectaban a los productos de algodón, terminó por apoyar el tímido proyecto de la mayoría moderada. En su opinión, éste no tendría ninguna efectividad inmediata, pero era un primer paso que podía favorecer a medio plazo el crecimiento de las exportaciones ${ }^{19}$.

En definitiva, con la decisión de no incluir el tema de los cereales en la reforma arancelaria, el gobierno y la mayoría moderada abrieron un espacio para plantear la eliminación parcial del prohibicionismo en los productos de algodón. Alentando las expectativas exportadoras para el trigo nacidas desde 1846, lograron fraccionar la coalición prohibicionista surgida en 1820. Aunque representantes de los propietarios y de los intereses agrícolas castellanos, como Moyano, siguieron apoyando la posición de los diputados catalanes contraria a la reforma, la práctica totalidad de los diputados andaluces, tanto los representantes de las provincias del litoral más vinculados a intereses exportadores, como los de las provincias del interior, secundaron la reforma ${ }^{20}$. Las tesis de los que veían en los mercados exteriores un motor de cre-

DSC-CD, 14/06/1849, p. 2590.

DSC-CD, 16/06/1849, p. 2.639.

DSC-CD, 16/06/1849, p. 2.640.

En concreto, cifraba los excedentes en un año normal en unos dos millones de fanegas. DSC-CD, 16/06/1849, p. 2.644.

DSC-CD, 22/06/1849, p. 2.861.

20 La votación del proyecto en DSC-CD, 23/06/1849, p. 2.928. 
cimiento se habían extendido desde la anterior reforma de 1841. Pero también se trataba de un primer paso para reducir la negativa relación de intercambio de algunas zonas con respecto a Cataluña ${ }^{21}$.

\section{Mercados de trigo y crisis de subsistencias, 1849-1858}

Durante la tramitación del proyecto de reforma arancelaria de 1849, García Barzanallana afirmó que la producción triguera española ya no tenía necesidad del prohibicionismo porque podía sobrevivir sin problemas con la implantación de un derecho protector adecuado. Esta opinión, por supuesto, no era unánimemente compartida, ni siquiera era mayoritaria. De hecho, la regulación del comercio exterior de cereales quedó fuera de la reforma arancelaria. Ni siquiera se pudieron afrontar ligeros retoques de la ley de 1834, que, al fin y al cabo, era el producto de un gobierno preconstitucional, ni se pudo avanzar en la reglamentación de las exportaciones de trigo, aspecto que había resultado decisivo durante la crisis de subsistencias de 1847. Como reconoció el mismo García Barzanallana, ningún gobierno moderado tenía la fuerza política suficiente para emprender reformas en el comercio de cereales.

En ese contexto político es necesario analizar la evolución de los mercados de trigo, tanto en la llamada periferia como en el interior, así como la influencia que el mercado internacional pudo tener sobre ambas áreas.

El Cuadro 1 recoge las variables fundamentales para entender la situación de los mercados de trigo entre 1849 y 1858. Hasta 1852, se trataría de una etapa de precios bajos, tanto en las zonas litorales como en el interior. Un promedio de 44 reales por fanega para Barcelona, o de 40 para Jerez, supone precios muy moderados si nos atenemos a la serie histórica registrada desde la instauración del prohibicionismo. La existencia en Inglaterra de unos precios más bajos o similares a los del litoral español no propició la exportación de trigo. Podemos hablar de un mercado internacional con abundantes excedentes que, a pesar de la liberalización comercial de Gran Bretaña, no sufrió fuertes tensiones en sus precios.

En ese contexto, el prohibicionismo español actuó como un freno para evitar que los precios en el litoral cayeran por debajo de los 40 reales por fanega. Esta es la situación que está detrás de las expresiones de optimismo de aquellos diputados que

21 El déficit en la balanza comercial de algunas zonas de España con respecto a Cataluña fue un tema frecuentemente debatido en la prensa. Para algunos representantes de las zonas exportadoras, como el andaluz Sánchez Silva, el prohibicionismo incrementaba dicho déficit. El debate se puede seguir en Guía del Comercio, 369, 29/01/1849, pp. 25-27. 


\section{CUADRO 1}

COMERCIO EXTERIOR Y PRECIOS DEL TRIGO, 1849-1858

(cantidades en fanegas y precios en reales por fanega)

\begin{tabular}{|c|c|c|c|c|c|c|c|}
\hline \multicolumn{3}{|c|}{ Cantidades } & \multicolumn{5}{|c|}{ Precios } \\
\hline Años & Exportadas & Importadas & Barcelona & Jerez & Interior & Inglaterra & Odessa \\
\hline 1849 & 44.582 & & 48 & 37 & 29 & 42 & \\
\hline 1850 & 81.734 & & 383 & 824 & & 38 & 23 \\
\hline 1851 & 93.344 & & 464 & 426 & & 35 & 20 \\
\hline 1852 & 92.648 & & 444 & 125 & & 38 & 22 \\
\hline 1853 & 805.734 & & 444 & 227 & & 49 & 24 \\
\hline 1854 & 1.696 .918 & & 534 & 738 & & 67 & 29 \\
\hline 1855 & 3.591 .437 & & 60 & 51 & 39 & 69 & \\
\hline 1856 & 960.379 & 1.277 .797 & 727 & 654 & & 64 & 43 \\
\hline 1857 & 31.811 & 5.250 .506 & 587 & 67 & & 53 & 36 \\
\hline 1858 & 80.806 & 3.532 .226 & 524 & 842 & & 42 & 30 \\
\hline Total & 7.479.394 & 10.060 .529 & & & & & \\
\hline
\end{tabular}

Fuentes: Las cantidades exportadas e importadas proceden de GEHR (1985), p. 356; los precios de Barcelona, de Garrabou, Tello y Roca (1999), p. 450; los de Jerez, de Caro y Rodway (2002); los del interior peninsular , de Barquín (2001); y los de Inglaterra y Odessa, de Gallego (2004), pp. 93-99.

ensalzaban el desarrollo agrícola experimentado, capaz de asegurar el abastecimiento a unos precios moderados. En estas condiciones, es posible que la sustitución del prohibicionismo por un sistema de derechos protectores no hubiera implicado una pérdida sustancial de los mercados litorales para el trigo del interior. Pero como la posibilidad de un aprovisionamiento exterior más barato era real, los precios hubieran tendido a descender. De hecho, los precios en Barcelona entre 1849 y 1852 fueron más altos que en Inglaterra.

Sin embargo, desde 1853 la coyuntura tendió a cambiar de modo significativo. Las dificultades generadas por la Guerra de Crimea en el comercio internacional de trigo, que llegaron a suponer la práctica interrupción del suministro de trigos rusos, provocaron un apreciable crecimiento de los precios en Gran Bretaña, incrementándose éstos un 30 por 100 respecto a 1852. La nueva situación favoreció la competitividad del trigo español y las exportaciones se dispararon. En 1853 se extrajeron más de ochocientas mil fanegas, un 30 por 100 más que en 1846, un año de graves problemas de abastecimiento en Europa. Quizá lo que más deba remarcarse sea que, a diferencia de lo ocurrido entonces, el notable volumen de exportaciones habido en 
1853 no implicó un crecimiento apreciable de los precios en el litoral, aunque en el interior se elevaron un 8 por 100. Da la impresión de que las existencias generadas por una serie de años de buenas cosechas facilitaron las ventas al exterior, sin que se produjeran desajustes en el abastecimiento interno.

La tendencia iniciada en 1853 se acentuó en los dos años siguientes. Un nuevo aumento de los precios del trigo del 36 por 100 en el mercado británico en 1854, propició que las exportaciones trigueras españolas se duplicaran respecto al volumen récord de 1853. Pero esta vez los efectos sobre los precios en los mercados españoles fueron más apreciables. En los del litoral, el incremento respecto al promedio correspondiente a 1849-1853 se situó entre el 12 y el 19 por 100, mientras que en el interior llegó al 41 por 100. La intensa actividad exportadora generó, sobre todo, fuertes tensiones en los precios de los mercados productores del interior.

Durante 1855, los altos precios del mercado británico siguieron impulsando las exportaciones, que, de nuevo, casi se duplicaron respecto a 1854. Los más de tres millones y medio de fanegas exportados superaron ampliamente los cerca de dos millones que se suponía se obtenían, en un buen año, como excedentes. Los precios de los mercados españoles siguieron subiendo y alcanzaron niveles que se consideraban indicadores de hambre y escasez. En este contexto, resulta muy revelador que los fallidos proyectos de reforma arancelaria presentados en 1855 y en $1856^{22}$ no incluyeran ninguna modificación de la legislación prohibicionista que regulaba la importación de trigo. Ni en los momentos más favorables para la producción triguera del interior, cuando era difícil encontrar una alternativa de abastecimiento en el exterior debido a la escasez generalizada, se intentó un cambio del marco arancelario del trigo.

Sin embargo, los obstáculos para exportar trigo sí que fueron un elemento central del debate parlamentario. Los problemas de abastecimiento y la carestía originaron los típicos movimientos populares contra las exportaciones. Ya en febrero de 1855 algunos diputados denunciaron las dificultades para efectuar las ventas al exterior, provocadas por grupos de personas que intentaban impedir los embarques.

En concreto, el diputado asturiano Ruiz Gómez expuso que las autoridades locales tendían a suspender los embarques ante las protestas populares, en momentos en que, cerrados los mercados de Odessa, afluían los pedidos hacia España. En consecuencia, continuó, "si el Gobierno no procura por medio de la importación, o buscando otro remedio análogo, que la exportación sea real y efectiva, y no ficticia, como es hoy, nos encontraremos en el mismo caso que si la exportación de cereales fuese prohibida ${ }^{23 "}$. En aquella ocasión, el ministro de la Gobernación, Santa Cruz,

22 El proyecto de reforma arancelaria de 1855 fue presentado por el ministro Juan Bruil. El de 1856, fue auspiciado por el ministro Santa Cruz, que sustituyó a aquél.

23 DSC, $16 / 02 / 1855$, p. 2.225. 
observó que se disponía de suficientes existencias en el país, que se esperaba, además, una buena cosecha y que, por último, no se daban las condiciones legales para autorizar la libre importación de cereales, aunque defendería el derecho a practicar la libre exportación frente a cualquier oposición que pudiera surgir. La voluntad del gobierno era hacer frente a los conflictos puesto que “...en todas partes se encuentra la Milicia Nacional deseosa de conservar el orden público, de proteger la propiedad...24".

A la vista de las exportaciones efectivamente realizadas en 1855, el gobierno se tomó en serio la defensa de la libre exportación de trigo, dada la cifra récord alcanzada. Por tanto, no es extraño que los incidentes, asaltos a panaderías o almacenes, y bloqueos de los transportes de trigo desde el interior, se reprodujeran con cierta frecuencia y se intensificaran en los últimos meses del año, a medida que los precios continuaron su marcha ascendente ${ }^{25}$.

El gobierno, preocupado por la proliferación de incidentes, ordenó a los responsables políticos de las provincias que recogiesen datos sobre los precios del trigo y las existencias disponibles ${ }^{26}$. Aunque tras la cosecha de 1855 los precios no descendieron, sino que acumularon una importante subida respecto al promedio de años anteriores, el gobierno decidió interpretar de forma positiva los datos sobre existencias, la verdad que escasamente fiables, y no adoptó ninguna medida especial. Si bien proclamó que llegado el momento aplicaría la orden de 23 de marzo de 1847, autorizando las importaciones y prohibiendo las exportaciones, en realidad no mostró mucha diligencia en su cumplimiento ante la constante presión de los grupos de productores y comerciantes de trigo, empeñados en aprovechar la favorable coyuntura $^{27}$.

En enero de 1856, los precios superaron en el litoral andaluz los 70 reales, nivel que permitía dar vía libre a la importación de acuerdo con lo contemplado en el decreto de 1834; en el interior se situaron en unos extraordinarios 44 reales. Ante esta situación, los conflictos se redoblaron en Cádiz y en otros lugares de Andalucía ${ }^{28}$. Sin embargo, tan sólo se adoptaron medidas locales para prohibir la exportación o autorizar la importación en Sevilla o Cádiz. El gobierno confiaba en controlar la situación con medidas parciales para evitar un cambio global de la regulación del comercio de

DSC, 16/02/1855, p. 2.224 .

Garrabou (1980); Lida (1972); Bernal (1979); Moreno (2003).

Garrabou (1980) ha publicado y comentado El expediente de la Dirección General de Comercio, en el que se recogen las directrices del Gobierno durante la crisis de 1856-1857. En dicho documento se resumen las existencias de trigo de acuerdo con las informaciones recibidas de las provincias.

Nuevamente, en diciembre de 1855, algunos diputados, como Ruiz Gómez y Moyano, exigieron al Gobierno que mantuviera la libertad de exportación frente a cualquier tipo de alteración del orden público. DSC, 29/12/1855, pp. 9.448-9.458.

Lida (1972); Bernal (1979). 


\section{CUADRO 2}

LOS PRECIOS DEL TRIGO, 1855-1858

(reales por fanega y números índice, base 100 = 1849-1854)

\begin{tabular}{lccccc}
\hline & Períodos & Interior & \multicolumn{3}{c}{ Jerez } \\
\hline $1849-1854$ & & 29 & 100 & 42 & 100 \\
\hline \multirow{1}{*}{$\mathbf{1 8 5 5 - 1 8 5 6}$} & julio-octubre 40 & & 137 & 51 & 120 \\
& noviembre-febrero & 44 & 150 & 63 & 149 \\
& marzo-junio 45 & & 154 & 68 & 162 \\
\hline $\mathbf{1 8 5 6 - 1 8 5 7}$ & julio-octubre 58 & & 201 & 81 & 193 \\
& noviembre-febrero & 80 & 275 & 93 & 222 \\
& marzo-junio & 79 & 272 & 75 & 179 \\
\hline $\mathbf{1 8 5 7 - 1 8 5 8}$ & julio-octubre 58 & & 200 & 59 & 141 \\
& noviembre-febrero & 43 & 148 & 55 & 130 \\
& marzo-junio & 41 & 142 & 47 & 113 \\
\hline $\mathbf{1 8 5 8 - 1 8 5 9}$ & julio-octubre 44 & & 151 & 49 & 117 \\
& noviembre-febrero & 40 & 137 & 47 & 112 \\
& marzo-junio 44 & & 152 & 56 & 134 \\
\hline
\end{tabular}

Fuentes: Caro y Rodway (2002), y Barquín (2001).

trigo. Como se aprecia en los debates del Congreso, el gobierno no sólo se opuso a cambios en la legislación que reglamentaba el comercio exterior de trigo, - por ejemplo, a la proposición de Figuerola en cuanto a reducir los precios reguladores para autorizar la importación-, sino que, incluso, se mostró muy reticente a aplicar el propio decreto de 1834, pese a que se superasen en el litoral los 70 reales por fane$\mathrm{ga}^{29}$. Es posible que sólo intentase ganar tiempo antes de la próxima cosecha.

Sin embargo, en el mes de junio de 1856 los precios del trigo superaron en el interior el elevado nivel de 50 reales la fanega, lo que era indicativo de otra cosecha muy insuficiente. Los motines y tumultos que se sucedieron durante dicho mes revelan lo insostenible de la situación. Las movilizaciones populares se transformaron en una denuncia clara de la parcialidad del gobierno en favor de los intereses de los propietarios y los comerciantes de trigo. La protesta evidenciaba con claridad las con- 
tradicciones de un régimen liberal que, al tiempo que proclamaba y decía defender la libertad económica y el libre funcionamiento de los mercados, no era capaz de autorizar las importaciones de trigo en una situación desesperada, ni siquiera cuando se alcanzaban las condiciones marcadas por la propia norma prohibicionista. Esa flagrante contradicción entre una defensa a ultranza de la libertad de exportación y la prohibición de importar se convirtió en insoportable en un período de escasez y carestía. Las movilizaciones populares eran la respuesta a esta práctica tan restrictiva del régimen liberal, que acentuaba el carácter oligárquico de su estructura política.

Las disensiones en el gobierno sobre el modo de afrontar la crisis, sobre todo a la hora de responder a la conflictividad social, desembocaron en la expulsión de los progresistas de aquél. Su incapacidad para afrontar reformas arancelarias significativas durante el bienio, puesta dramáticamente de manifiesto durante la crisis de subsistencias, les situó ante el dilema de utilizar la represión para controlar las movilizaciones populares ${ }^{30}$. Solamente en este momento, cuando el gobierno estaba próximo a su disolución, se autorizó la libre importación de trigo (orden de 11 de julio) con el objetivo de paliar la grave escasez. Pero en aquel momento la situación ya no era fácilmente reversible.

Pese a la penuria y a la movilización popular, en la primera mitad de 1856 se exportaron más de novecientas mil fanegas de trigo. A partir de julio, los precios alcanzaron nuevos máximos, tanto en el interior como en el litoral. La liberalización de las importaciones llegó tarde. En ese momento de crisis general no era fácil comprar trigo más barato en parte alguna. De hecho, hasta fin de año, se importaron más de un millón de fanegas, pero los precios siguieron creciendo. De noviembre de 1856 a febrero de 1857, los precios alcanzaron los máximos de la crisis, con aumentos del 122 por 100 en el litoral y del 175 por 100 en el interior respecto al promedio concerniente a 1849-1854. Como era de esperar, la libertad de importación fue más efectiva en el litoral que en el interior para moderar la carestía. Los precios del transporte del litoral al interior fueron un factor negativo añadido a la escasez generalizada.

En el siguiente cuatrimestre, entre marzo y junio de 1857, los precios empezaron a bajar en el litoral, un 43 por 100 respecto al cuatrimestre anterior, mientras que en el interior apenas se recortaron un 3 por 100. La mayor afluencia de importaciones generó una situación paradójica: la zona consumidora del litoral tuvo precios más bajos que la zona productora del interior. Como los precios se mantuvieron por encima del umbral regulador de 70 reales por fanega, incluso en el interior, el gobierno no tuvo más remedio que prorrogar la libertad de importación hasta el 31 de diciem-

30 El impacto de las movilizaciones populares y la subsiguiente crisis de gobierno en Kiernan (1970), p. 240, y Moreno (2003), p. 132. 
bre de 1857. Esta medida, al coincidir con la incorporación a los mercados de la nueva cosecha desde el mes de julio, provocó un recorte sustancial de las cotizaciones en el segundo semestre del año y marcó el final de la crisis.

En 1857, por primera vez en cuatro años, no hubo exportaciones de trigo, no sólo a causa de las actuaciones administrativas para prohibirlas, sino, sobre todo, porque los precios de Londres fueron más bajos que los del interior peninsular. Por el contrario, se importaron más de cinco millones de fanegas. En este año pueden verse con claridad las desastrosas consecuencias del prohibicionismo instaurado en 1820. Como señaló Figuerola, beneficios extraordinarios para propietarios y especuladores, hambre y carestía para el resto de la sociedad. Debido a esta gestión tan parcial de la crisis, la alteración de los mercados fue tan profunda que, de marzo a junio de 1858 , los precios siguieron siendo superiores, en un 48 por 100 en el interior y en un 30 por 100 en el litoral, respecto al promedio de 1849-1854. Además, tampoco en 1858 hubo casi exportaciones de trigo, los precios de Londres fueron inferiores o iguales a los del interior peninsular, y se importaron más de tres millones de fanegas.

En definitiva, la fiebre exportadora de trigo desatada con la Guerra de Crimea, manteniendo al mismo tiempo la prohibición de importar, desencadenó efectos claramente negativos. Durante todo el lapso 1849-1858, las importaciones trigueras superaron, en cantidad y en valor, a las exportaciones. El déficit resultante se aproximó al 34 por 100 respecto a las cantidades exportadas y al 6 por 100 respecto al valor de las exportaciones efectuadas. El impacto social fue enorme, los progresistas fueron alejados del poder y, en suma, el régimen liberal demostró su incapacidad para desprenderse de sus rasgos oligárquicos.

\section{Tras la crisis: el debate sobre la continuidad de la libertad de impor- tación}

Ya desde febrero de 1858, varios meses antes de que finalizara la última prórroga que autorizaba la libertad de importación, los propietarios agrícolas y los labradores empezaron a movilizarse para lograr la vuelta al régimen prohibicionista. En una exposición enviada por la Diputación provincial de Sevilla, se pidió al gobierno que suspendiera la libertad de importación antes de la próxima cosecha, para evitar nuevos descensos de los precios del trigo y la ruina inminente de los agricultores ${ }^{31}$.

31 "Paralizada completamente la extracción, aun para las costas, es de temer que si continúan abiertas las fronteras cuando comience la recolección afluyendo los granos extranjeros sobre las crecidas existencias del país, se envilezcan tanto los precios que ni aun cubran los gastos de producción". Expediente General sobre subsistencias (1855-1858), (Garrabou, 1980, p. 336). 
Cuando los precios del interior aún eran superiores en un 45 por 100 al promedio del período 1849-1854, y los de la costa en un 19 por 100, los agricultores querían cerrar la puerta de la importación para mantener altos los precios en el interior e impedir mayores reducciones de los mismos en las ciudades litorales. El objetivo era evitar que en éstas el precio cayera por debajo de los 50 reales por fanega.

En sentido diametralmente opuesto se pronunció la Junta de Comercio de Cádiz. En un documento dirigido a las Cortes, fechado en abril de 1858, pidió la definitiva liberalización del comercio de trigo, tanto en lo tocante a la importación como a la exportación ${ }^{32}$. Era un texto muy similar al publicado por la Sociedad Económica de Cádiz con ocasión de la anterior crisis de subsistencias de $1847^{33}$. Se solicitaba que se derogase definitivamente la prohibición de importar trigo, instaurando el libre comercio de granos, y se afirmaba que los problemas de abastecimiento y de carestía sufridos durante las crisis de subsistencias eran consecuencia de una mala regulación del comercio de cereales.

Tomando como referencia la experiencia inglesa tras la abolición de las Corn Laws (1846) y la evolución de los precios del trigo, tanto en el mercado británico como en el español, los comerciantes de Cádiz afirmaban, de un lado, que la libertad del comercio de granos era la única alternativa para asegurar un abastecimiento regular, estable y a precios reducidos, y, de otro, que la libre importación de trigos extranjeros podía mantenerse sin provocar la ruina de los agricultores del interior. Mediante el análisis de las series de precios del trigo de los últimos años, deducían que en tiempos normales, en años de buena cosecha e, incluso, regular, los bajos precios del trigo español en las ciudades del litoral hacían inviable la importación de trigo extranjero por no generar rentabilidad alguna. Incluso en los años excepcionales de malas cosechas, continuaban los comerciantes gaditanos, la importación de trigo era una especulación arriesgada y difícil. Es más, a partir de la autorización para importar trigo en 1847, o desde 1856, las cantidades importadas eran relativamente pequeñas respecto al consumo total y no desplazaron en ningún caso a los trigos nacionales. La mejor prueba de ello era el crecimiento de las exportaciones españolas de trigo hacia el mercado británico. Nadie podía entender que los trigos españoles no fueran capaces de defenderse de la competencia exterior en el mercado propio y, sin embargo, lucharan con éxito en el mercado británico. Necesariamente la libertad de exportación tenía que ir unida a la libertad de importación. Por tanto, eliminar la prohibición e incluir los cereales en el arancel estableciendo un "derecho de balanza ${ }^{34 "}$ no tendría un efecto negativo sobre la agricultura española. Al contra-

Junta de Comercio de Cádiz, A las Cortes, Cádiz, 21/04/1858.

Se publicó en el diario gaditano El Comercio, 24/05/1847, pp. 6-7.

Se proponía un derecho de balanza del 5 por 100 ad valorem. 
rio, concluían los comerciantes gaditanos, las ventajas del comercio libre de cereales sobre la prohibición eran evidentes. En primer lugar, se eliminaba la posibilidad de una especulación desmedida y, en segundo término, se reducían los "pretextos a los clamores públicos" ${ }^{\prime 35}$. En definitiva, se obtendría una mayor regularización del mercado y se facilitaría el consumo.

La crítica del prohibicionismo que contenía el escrito de los comerciantes gaditanos, como responsable de las violentas fluctuaciones de precios tanto en las ciudades del litoral como en las zonas del interior, era muy difícil de rebatir. Pero las evidencias presentadas acerca de los inexistentes efectos de la apertura de los mercados sobre la agricultura española eran más endebles. Para el Negociado de Comercio no resultaban creíbles. De hecho, éste desaconsejó la petición de la Junta de Comercio de Cádiz porque supondría un cambio muy radical de la legislación en vigor y podría "lastimar los intereses de la industria agrícola de nuestro país"36. Aquél proponía medidas más moderadas, como la reducción del precio regulador, permitiéndose la importación cuando éste alcanzase los 60 reales por fanega, mientras se preparaba una reforma general de la normativa vigente.

La propuesta de liberalización de la Junta de Comercio de Cádiz fomentó un amplio debate público sobre la conveniencia, o no, de mantener la legislación prohibicionista. La discusión fue alentada, además, por la circular de García Barzanallana, en ese momento Director General de Aduanas y Aranceles, en la que solicitaba datos a los gobernadores provinciales para considerar la posibilidad de una reforma del decreto de $1834^{37}$. Las opiniones emitidas, recogidas en el expediente de la Dirección de Comercio, se inclinaron, en su mayoría, por mantener la prohibición de importar. Únicamente la Sociedad Económica matritense y el Ayuntamiento de Madrid se mostraron partidarios de superar la prohibición y de implantar el libre comercio de cereales. Asimismo, los gobernadores de Almería y Málaga recomendaron el mantenimiento de la autorización temporal de importar, dados los problemas de abastecimiento existentes en sus ciudades.

A favor de terminar con la prórroga que autorizaba la importación y de restablecer la legislación prohibicionista de 1834 se pronunciaron instituciones y organismos de las zonas productoras (Sevilla, Lérida, Huesca, Gerona, Cádiz, Ávila, Palencia, Zaragoza, etc.) y de la más importante área deficitaria, Barcelona. Los argumen-

\footnotetext{
A las Cortes, p. 5.

Garrabou (1980), p. 340.

Circular a los Gobernadores de provincia, pidiendo datos para la adopción de principios fijos sobre la importación de cereales extranjeros, 28/06/1858. García Barzanallana reconocía que "la experiencia ha venido a demostrar, así en el año 1847 como en el de 1855 y los siguientes hasta el actual, que la legislación dictada en 1834, para facilitar la entrada de los granos extranjeros cuando los nacionales lleguen a alcanzar un precio de hambre, es ineficaz para conseguir el abastecimiento inmediato de los mercados y la nivelación en los precios del trigo y de las demás semillas alimenticias".
} 
tos expuestos por los primeros incidían en el problema que siempre habían subrayado: la falta de competitividad de los trigos españoles frente a los rusos o norteafricanos. Autorizar la importación de cereales, aunque se estableciera un derecho protector, reduciría los precios e implicaría la pérdida definitiva de los mercados del litoral para los trigos del interior ${ }^{38}$. En consecuencia, dañaría de forma muy directa los intereses agrícolas y ocasionaría un empobrecimiento general.

Es comprensible, hasta cierto punto, que las zonas cerealistas se pronunciaran unánimemente a favor del restablecimiento del prohibicionismo, puesto que el cambio modificaba un modelo de acumulación muy favorable. Pero también hay que destacar que, después de una crisis de subsistencias tan dura y de efectos sociales tan visibles, la principal zona consumidora con un déficit estructural constante, Barcelona, también se mostrara en contra del libre comercio de granos.

No sólo los grupos relacionados con la agricultura demandaron la vuelta del prohibicionismo, la Junta provincial de Agricultura, el Comisario Regio de Agricultura de Barcelona o el Instituto Agrícola Catalán de San Isidro, sino también la Diputación de Barcelona y, más llamativo aún, la Junta de Fábricas de Cataluña. Este organismo, que agrupaba a los industriales catalanes, también dirigió un escrito a las Cortes defendiendo el retorno de la legislación restrictiva ${ }^{39}$. Su exposición se ceñía, sobre todo, a refutar los datos y argumentos de la Junta de Comercio de Cádiz.

En primer lugar, el documento de la Junta de Fábricas de Cataluña señalaba que los promedios de precios del trigo en años normales en las ciudades del litoral ofrecidos por la Junta de Comercio de Cádiz no eran fiables. En realidad, eran mucho más altos, situándose a su parecer entre los 44 y 50 reales por fanega. Por tanto, la libre importación de trigos rusos o harinas norteamericanas sí que representaba una competencia insuperable para los trigos del interior. Este análisis de precios de la Junta de Fábricas era mucho más ajustado a las series históricas que hemos podido reconstruir. Pero la conclusión era interesada y es necesario matizarla.

El problema es determinar a partir de qué precios los comerciantes de las ciudades del litoral podían considerar ventajosa la importación de trigo. No creo que sea suficiente, como plantea Gallego ${ }^{40}$, tener en cuenta como única referencia los precios del puerto de Londres. Es más clarificador partir de los datos de los hipotéticos importadores. Para los comerciantes de Cádiz el umbral que determinaba una importación remuneradora para las ciudades del litoral se situaba en los 50 reales

38 En un escrito enviado por comerciantes, propietarios y labradores de Zamora, de febrero de 1859, que hallamos en el Expediente General sobre subsistencias (1855-1858), se reclama abiertamente la obtención de los beneficios extraordinarios propios de años de malas cosechas, que dejarían de afluir con el establecimiento de un arancel a la importación que estabilizase los mercados (Garrabou, 1980, p. 353). 


\section{CUADRO 3}

DISTRIBUCIÓN REGIONAL DE LA IMPORTACIÓN DE TRIGO EN 1857 Y 1858

\begin{tabular}{lcrrr}
\hline Zonas & $\begin{array}{c}\text { Fanegas } \\
\text { importadas }\end{array}$ & Porcentajes & Habitantes & $\begin{array}{c}\text { Fanegas por } \\
\text { habitante }\end{array}$ \\
\hline Cataluña & $2.921 .64035,0$ & 1.362 .408 & 2,10 \\
Cantabria/Vizcaya/Guipúzcoa & $1.346 .44316,0$ & 539.705 & 2,50 \\
Levante & $1.335 .19916,0$ & 1.657 .777 & 0,80 \\
Andalucía Oriental & $1.093 .99213,0$ & & 1.234 .054 & 0,90 \\
Andalucía Occidental & 883.5461 & \multirow{2}{*}{1,0} & 576.820 & 1,50 \\
Baleares & $667.8678,0$ & & 267.533 & 2,50 \\
Galicia/Asturias & $46.5211,0$ & & 1.957 .785 & 0,02 \\
\hline Total 8.295.208 & & \multirow{2}{*}{$\mathbf{1 0 0 , 0}$} & $\mathbf{7 . 5 9 6 . 0 8 4}$ & $\mathbf{1 , 1 0}$ \\
\hline
\end{tabular}

Fuentes: Kondo (1990), pp. 114-115, y Anuario Estadístico de España de 1858.

por fanega. Pero este umbral podía ser menor si se establecían vínculos comerciales permanentes y directos con los centros productores, como Odessa ${ }^{41}$, o si el arancel protector disminuía en épocas de escasez.

Aunque optemos por un umbral alto como el propuesto por los comerciantes de Cádiz, que incluía el consiguiente arancel protector, debemos concluir que seguía existiendo un abastecimiento exterior más barato para las ciudades del litoral. Desde 1854 , los precios del trigo superaron los 50 reales por fanega. Por tanto, si se hubiera sustituido el prohibicionismo por un sistema proteccionista, las importaciones de trigo hacia el litoral mediterráneo y atlántico se hubiesen realizado. Pero tales importaciones no hubieran supuesto necesariamente una pérdida sustancial de la cuota de mercado para el trigo del interior, aunque si una tendencia a la baja de los precios.

Solamente con el aumento de las exportaciones españolas de trigo, impulsadas por los atractivos precios del mercado británico, y con la consiguiente alza de precios en los mercados litorales, las importaciones de trigos más baratos del Norte de África o de otros puntos del Mediterráneo hubieran proliferado en las ciudades costeras. Ello habría contribuido a una moderación de los precios y a reducir la escasez.

41 Es decir, tráficos de ida y vuelta con la consiguiente reducción del precio del transporte. Para las actividades de los comerciantes de Barcelona o Cádiz con Odessa y otros puntos antes de la legislación prohibicionista, véanse Fradera (1987) o Martínez Ruiz (2005). 
Aunque, claro está, también se hubieran reducido los beneficios extraordinarios de agricultores y comerciantes.

La identificación de los industriales catalanes con los grupos cerealistas era tan notable que tampoco veían contradicción en la simultaneidad de la prohibición de importar y la libertad de exportar. Entendían que las ganancias obtenidas en las épocas de escasez contribuían a aumentar la capitalización de la economía española ${ }^{42}$. En definitiva, los industriales catalanes seguían situados en las mismas posiciones que les llevaron a secundar la coalición prohibicionista de $1820^{43}$. Es más, rechazaban explícitamente cualquier comparación con la situación inglesa, es decir, una coalición de los núcleos urbanos contra los intereses agrícolas, porque "no existen además las quejas de la clase industrial, cuya suerte está identificada con los agricultores españoles que son sus consumidores".

Aparentemente, los industriales catalanes podían estar interesados en una reducción drástica del precio del trigo que mermase los costes salariales reales y aumentase el poder de compra de la mayoría de la población. Era la tesis que sostenía Figuerola. En este sentido, les hubiera convenido una alianza con los comerciantes gaditanos. Pero los modelos económicos que defendían unos y otros eran contrapuestos ${ }^{44}$ y dicha coalición resultó imposible. Mientras que los industriales catalanes propugnaban un desarrollo industrial con un mercado interior reservado, los comerciantes gaditanos aspiraban al libre ejercicio de la actividad comercial con un instrumento tan poderoso como el puerto franco.

Para los industriales catalanes, la trayectoria histórica de la agricultura española bajo la legislación prohibicionista era globalmente positiva porque el crecimiento de la producción había sido mayor que el aumento de la población. Frente al crónico déficit de épocas anteriores, ahora existían excedentes. La prohibición de importar había facilitado ese proceso y era necesario mantenerla. Esta posición, que no tenía en cuenta la carestía y la escasez de los últimos años, estaba inspirada posiblemente por el temor a que un pronunciamiento más favorable hacia las reformas en el comercio exterior del trigo propiciase, asimismo, reformas arancelarias más profundas en los productos textiles. Eran consecuentes con lo que habían defendido ante la reforma arancelaria de 1849. Seguir manteniendo la prohibición de importar trigo era el medio para evitar una mayor liberalización de los productos textiles ${ }^{45}$.

\footnotetext{
$42 \quad$ A las Cortes, p. 4.

43 El desarrollo del prohibicionismo en Cataluña ha sido analizado por Lluch (1973), Sánchez (1990) y Artal (2000).

44 Costas (2000), p. 461, señala que las distintas opciones de desarrollo económico que se planteaban, agrarismo o industrialismo, no se identificaban automáticamente con las alternativas de la política comercial.

45 A las Cortes, p. 7.
} 
Nuevamente, la coalición entre la zona urbana con mayor déficit, Barcelona, y los productores cerealistas logró evitar reformas en la legislación prohibicionista. Las propuestas liberalizadoras de los comerciantes madrileños o gaditanos quedaron aisladas frente al peso político de la coalición entre cerealistas e industriales ${ }^{46}$. Finalizada la última prórroga para importar trigo, en diciembre de 1858, el gobierno, en ese momento integrado por miembros de la Unión Liberal, no concedió nuevas autorizaciones ni presentó proyecto de reforma alguno sobre el decreto de 1834.

\section{Las consecuencias de una prohibición renovada: mercados y crisis de subsistencias, 1859-1869}

Pese a las evidencias acumuladas sobre los efectos negativos del prohibicionismo durante la crisis de subsistencias entre 1856 y 1858, suficientemente realzadas en el debate público, ninguno de los posteriores gobiernos de Isabel II fue capaz de modificar la normativa fijada en 1834. Ni una reforma limitada, como la reducción de los precios que regulaban la admisión del trigo extranjero, ni la supresión de la prohibición, lograron la suficiente mayoría en el gobierno o en las Cortes como para convertirse en una realidad. En un régimen representativo alimentado por una participación política muy restringida, la coalición entre cerealistas e industriales bloqueó sistemáticamente cualquier intento de modificar de forma permanente la prohibición de importar cereales.

Entre 1859 y 1869 se demostró con mayor claridad que el régimen prohibicionista había devenido en un mecanismo de extracción de rentas para grupos reducidos. En un contexto internacional de creciente liberalización, dominado por el acuerdo entre Francia y Gran Bretaña (tratado de Cobden-Chevalier de 1860), los principales socios comerciales de España, la normativa prohibicionista se mantuvo sin alteraciones ${ }^{47}$. Desde la perspectiva de la evolución de los precios del trigo, ello supuso que no tuviese lugar una reducción más pronunciada tras la crisis de subsistencias.

46 Únicamente algunos industriales harineros se sumaron a las peticiones para implantar la libertad de importar trigo, como medio para obtener una materia prima más barata. Pero, por supuesto, se manifestaron favorables a seguir manteniendo la prohibición de importar harinas. En este sentido se expresó $L a$ Industria Harinera de Reus en enero de 1859 (Garrabou, 1980, p. 351).

47 En mi opinión, no existió en este período ninguna flexibilización en el régimen arancelario triguero, como parece sugerir Gallego (2005), p. 266. Incluso, las autorizaciones para importar trigo no se concedieron de forma automática como recogía el decreto de 1834, sino tras las movilizaciones populares. 


\section{CUADRO 4}

COMERCIO EXTERIOR Y PRECIOS DEL TRIGO, 1849-1869

(cantidades en fanegas y precios en reales por fanega)

\begin{tabular}{|c|c|c|c|c|c|c|}
\hline \multicolumn{3}{|c|}{ Cantidades } & \multicolumn{4}{|c|}{ Precios } \\
\hline Años & Exportadas & Importadas & Barcelona Jerez & Interior & Inglaterra & Odessa \\
\hline $1849-1853$ & 223.609 & & 444026 & & 40 & 22 \\
\hline 1854-1855 & 2.644 .178 & & 564939 & & 68 & 29 \\
\hline $1856-1858$ & 357.665 & 3.353 .510 & 606554 & & 53 & 36 \\
\hline 1859 & 50.852 & 212.231 & 566039 & & 41 & 28 \\
\hline 1860 & 528.487 & & 576138 & & 48 & 34 \\
\hline 1861 & 790.409 & & 595744 & & 52 & 33 \\
\hline 1862 & 61.765 & & 576143 & & 51 & 30 \\
\hline 1863 & 43.654 & & 555942 & & 42 & 29 \\
\hline 1864 & 26.239 & & 565241 & & 38 & 25 \\
\hline 1865 & 388.471 & & 535034 & & 39 & 26 \\
\hline 1866 & 1.589 .409 & & 485637 & & 47 & 32 \\
\hline 1867 & 1.026 .324 & 629.959 & 527250 & & 60 & 39 \\
\hline 1868 & 54.103 & 10.604 .342 & 657466 & & 60 & 43 \\
\hline 1869 & 165.559 & 3.209 .933 & 515441 & & 45 & 29 \\
\hline
\end{tabular}

Fuentes: Las mismas del Cuadro 1.

Los precios del trigo en los mercados del litoral y del interior entre 1859 y 1865 no sólo no volvieron a los niveles anteriores a la Guerra de Crimea, sino que, incluso, fueron superiores a los de la etapa 1849-1855. El porcentaje de incremento se situó entre el 12 por 100 de Barcelona y el 28 por 100 de Jerez. Además, el promedio de los precios en los mercados del litoral superó hasta en un 25 por 100 el alcanzado en el mercado de Londres. Las superiores cotizaciones de los mercados españoles no eran resultado de tensiones de precios existentes en los mercados internacionales, sino consecuencia directa de la reimplantación del prohibicionismo. Mientras que Gran Bretaña importaba varios millones de fanegas y mantenía unos precios más reducidos, en España se prohibía la importación y se alcanzaban precios más elevados.

La imposibilidad de retornar a los precios del lapso 1849-1855 muestra, también, las limitaciones del crecimiento de la producción cerealista española. Si de 1853 a 1855 los precios comenzaron a subir debido al extraordinario aumento de las expor- 
taciones debido a la Guerra de Crimea, a partir de 1859 el escenario cambió por completo. Las exportaciones se redujeron drásticamente, siendo sólo de alguna significación en 1860 y 1861, y no volvieron a alcanzar los niveles de 1853-1856 hasta 1866, otro año de escasa cosecha generalizada. Por tanto, entre 1859 y 1865 se frustraron las expectativas de convertir a España en una región netamente exportadora de cereales. Es más, si observamos la resistencia al descenso de precios tanto en los mercados del litoral como del interior, podemos pensar que los excedentes anuales tendieron a reducirse. Habría que acumular más evidencias para determinar si este resultado fue consecuencia de la evolución de la demanda, del aumento de la población ${ }^{48}$, o de la oferta como efecto de un estancamiento de la inversión.

La existencia de altos precios del trigo en un contexto regulador prohibicionista mantuvo vivo el debate acerca de la necesidad de la reforma arancelaria. Los grupos librecambistas, más numerosos y mejor organizados desde $1859^{49}$, siguieron exponiendo argumentos para propugnar la definitiva abolición de la prohibición. En estos años, un texto de Figuerola sobre la cuestión de los cereales tuvo notable impacto $^{50}$. Para el economista catalán, la prohibición suponía un insoportable impuesto al consumo que perjudicaba a los más pobres. Entendía que el precio regulador fijado por el decreto de 1834 era sinónimo de hambre generalizada, imposible de remediar a corto plazo. Estudiando las crisis de subsistencias de 1847 y 1856-58, concluía que el encarecimiento del trigo debido a la deficiente legislación había tenido un influjo directo sobre la mortalidad. Cada real de aumento en el precio del trigo tenía su reflejo inmediato en esta última. Por ello, proponía una rápida eliminación de la prohibición de importar.

Cuando hacia 1863 empezó a tomar cuerpo la posibilidad de proceder a otra reforma arancelaria ${ }^{51}$, los grupos cerealistas redoblaron también su actividad. Desde las páginas de La España agrícola, Hidalgo de Tablada se alzó contra la posibilidad de autorizar la libre importación de cereales ${ }^{52}$. Subrayaba los argumentos de siempre. Que la situación en Inglaterra no era la misma que en España, ya que aquí existían excedentes que garantizaban el abastecimiento a unos precios razonables. Que si bien los precios del trigo habían subido, lo habían hecho menos que los de otros productos. Que la libertad de importación supondría la pérdida irremediable de los mercados del litoral ante los trigos extranjeros y un descenso generalizado de los precios en el interior. Hidalgo de Tablada insistía en que el "labrador tiene derecho a trabajar caro" para evitar el abandono de la actividad agrícola. Según él, existía en España un

\footnotetext{
48 La población española pasó de 12,29 millones en 1834 a 15,65 en 1860 (Pérez Moreda, 1997, p. 54).

49 Para el desarrollo del movimiento librecambista en esta etapa, Lebón y Sánchez (2000), pp. 509-517.

$50 \quad$ La Gaceta economista, 1862, 14/06/1862, pp. 411-429.

51 El ministro Salaverría presentó un proyecto de reforma arancelaria que, finalmente, fue retirado.

52 La España agrícola, 1863, 7, febrero de 1863, pp. 195-200.
} 
excedente de diez a veinte millones de fanegas que garantizaba la presencia de unos bajos precios, haciendo innecesaria y contraproducente la libertad de importación.

La presión política y social del grupo cerealista logró eliminar toda referencia al trigo en el proyecto de reforma arancelaria de Salaverría. En consecuencia, su aprobación se hizo imposible puesto que el resto de los sectores económicos, los grupos industriales principalmente, tampoco aceptaron medidas liberalizadoras que sólo les afectasen a ellos. Esta reforma arancelaria fallida de 1863 mostró que sólo un cambio de conjunto, que incluyera al comercio del trigo, podría garantizar una liberalización efectiva.

Los argumentos de Hidalgo de Tablada no resistieron la prueba de otro período de dificultades en el abastecimiento, iniciado en 1866. De nuevo, el crecimiento de los precios en Inglaterra y en el mercado internacional desató una oleada de exportaciones de trigo español. En 1866 el promedio anual del precio del trigo se incrementó un 19 por 100 en Inglaterra y un 23 por 100 en Odessa. Al ampliarse el diferencial respecto a los precios del interior español, las exportaciones comenzaron a fluir como en 1853. En el transcurso de 1866 se exportaron más de un millón y medio de fanegas de trigo. En esta ocasión, la situación límite sobrevino rápidamente. Mientras que la anterior etapa exportadora, de 1853 a 1855, se prolongó más de tres años antes de llegar a la crisis de subsistencias, extrayéndose más de siete millones de fanegas, en este momento la crisis llegó al cabo de un año con una exportación mucho más reducida.

En las ciudades de la bahía de Cádiz, ya en la primavera de 1867, se alcanzaron los fatídicos 70 reales por fanega, precio que obligaba a las autoridades a permitir la importación de trigo extranjero. Ello indicaba serios problemas de abastecimiento y la extensión del hambre entre los grupos sociales de menor renta. Y no era sólo un problema local, pues en el interior los precios también subieron de forma alarmante. Todo apuntaba a la repetición del desastre de 1856-1858 y, sin embargo, se mantuvo la misma regulación del comercio exterior de trigo que se había demostrado tan perjudicial. Las exportaciones no se contuvieron —superaron el millón de fanegas durante 1867-, y no se actuó con rapidez para autorizar la importación. Sólo en agosto, cuando se vio que la nueva cosecha era muy insuficiente y que los precios seguían subiendo en medio de intensas protestas sociales, el gobierno autorizó las importaciones de trigo.

Como en 1856, la libertad de importación no pudo generar un alivio inmediato de la situación. En 1867, el volumen exportado superó al de las importaciones, por lo que en la primavera de 1868 las condiciones eran dramáticas. También en esta ocasión los precios del trigo subieron más en el interior que en el litoral. En 1868 se importó la cifra record de más de diez millones de fanegas debido a una escasez realmente notable. La extensión de la protesta social a consecuencia de la carestía contribuyó decisivamente a la caída de la monarquía isabelina ${ }^{53}$.

53 La influencia de la gestión de la crisis de subsistencias en la revolución de 1868 ha sido destacada por Durán (1979), p. 316, y Sánchez Albornoz (1970). 


\section{CUADRO 5}

LOS PRECIOS DEL TRIGO, 1866-1870

(reales por fanega y números índice, base 100 = julio-octubre de 1866)

\begin{tabular}{lccccr}
\hline & Períodos & Interior & \multicolumn{3}{c}{ Jerez } \\
\hline \multirow{2}{*}{$\mathbf{1 8 6 6 - 1 8 6 7}$} & julio-octubre 38 & & 100 & 50 & 100 \\
& noviembre-febrero & 45 & 118 & 59 & 119 \\
& marzo-junio 50 & & 130 & 69 & 138 \\
\hline $\mathbf{1 8 6 7 - 1 8 6 8}$ & julio-octubre 49 & & 127 & 75 & 151 \\
& noviembre-febrero & 61 & 160 & 86 & 173 \\
& marzo-junio 72 & & 189 & 84 & 168 \\
\hline $\mathbf{1 8 6 8 - 1 8 6 9}$ & julio-octubre 64 & & 167 & 66 & 132 \\
& noviembre-febrero & 53 & 137 & 58 & 116 \\
& marzo-junio & 44 & 116 & 55 & 111 \\
\hline $\mathbf{1 8 6 9 - 1 8 7 0}$ & julio-octubre 37 & & 96 & 54 & 108 \\
& noviembre-febrero & 36 & 93 & 57 & 114 \\
& marzo-junio 38 & & 98 & 57 & 114 \\
\hline
\end{tabular}

Fuentes: Las mismas del Cuadro 2.

\section{La eliminación del prohibicionismo: la reforma arancelaria de Figuerola}

La revolución de septiembre de 1868 dio origen a un régimen liberal en el que, por primera vez, el sufragio universal masculino determinó la composición de la representación parlamentaria. Es preciso resaltar que la ampliación de la participación política a los varones mayores de 25 años propició que, por vez primera desde 1820, los partidarios de la liberalización arancelaria fuesen mayoritarios en las Cortes Constituyentes de 1869. Tras más de una década de actuación pública a favor de las reformas arancelarias, los llamados "economistas" accedieron al poder y tuvieron la oportunidad de ensayar sus propuestas. Desde el primer momento, el nuevo ministro de Hacienda, Figuerola, anunció que propondría una reforma arancelaria que recogería los principios que había defendido en los últimos años ${ }^{54}$.

54 Los postulados de la escuela "economista" y la reforma arancelaria de Figuerola, en Costas (1988), pp. 3449. El pensamiento económico de Figuerola, en Cabrillo (2000). Y el librecambismo industrialista de Figuerola, en Costas (2000), p. 475. 
En una de sus primeras intervenciones ante las Cortes Constituyentes, Figuerola señaló la contradicción que había acompañado al régimen liberal desde 1820: no se podía ser liberal en todas las esferas y reaccionario en la industrial. Las libertades conquistadas con el cambio político tenían que extenderse necesariamente al terreno económico $^{55}$. Poco tiempo después, presentó un proyecto de reforma arancelaria liberalizador dentro de la Ley de Presupuestos para el año 1869-187056. Durante el debate de la propuesta se advirtió que el prohibicionismo se había quedado sin representación parlamentaria. La controversia se centró en el grado de protección que había que proporcionar a los productores españoles, pero nadie cuestionó la desaparición de las prohibiciones.

El voto minoritario al dictamen de la Comisión de las Cortes y algunas enmiendas propusieron derechos más reducidos y tiempos de transición más cortos para su aplicación ${ }^{57}$, pero se descartó un cambio demasiado brusco para evitar riesgos innecesarios al nuevo régimen ${ }^{58}$. Por su parte, los antiguos prohibicionistas, reconvertidos en proteccionistas, exigieron derechos de entrada más altos que los recogidos en el proyecto del gobierno. El incombustible Madoz, que venía interviniendo desde la primera reforma arancelaria de 1841, mostró su alarma por el trato que dispensaba aquél a los cereales y las consecuencias negativas que tendría para Casti$11 a^{59}$. Precisamente, la protección que se debía establecer a los trigos y harinas ocupó una parte muy destacada del debate parlamentario sobre el proyecto de reforma arancelaria.

Figuerola contemplaba en su proyecto un derecho fiscal para el trigo de cinco reales por fanega, lo que suponía entre un 8 y un 9 por 100 de los precios del litoral ${ }^{60}$. Este limitado arancel fue muy criticado por los proteccionistas, que volvieron a plantear la imposibilidad de que los trigos del interior compitiesen en el litoral con los rusos o con los norteafricanos. Un arancel tan bajo provocaría un efecto muy negativo sobre la primera industria del país. Aunque no cuestionaron la necesidad de eliminar el prohibicionismo, si pugnaron por el establecimiento del máximo derecho fiscal, a fin de erigir una sólida defensa frente a la competencia exterior. En este sen-

$55 \quad$ DSCC, $8 / 03 / 1869$, p. 372.

56 Las famosas Bases para la reforma del arancel de Aduanas se encontraban en la letra C del artículo 9 de la Ley de Presupuestos para el año 1869-1870. El dictamen y los votos particulares de la Comisión, en DSCC, 19/06/1869.

57 Voto minoritario de Gabriel Rodríguez en DSCC, 26/06/1869, p. 3.169.

58 Figuerola advirtió de los peligros de la oposición carlista e isabelina si se provocaba un descontento exagerado (DSCC, 27/06/1869, p. 3.196).

59 La primera intervención de Madoz, en DSCC, 27/06/1869, p. 3.198.

60 Representaba el 8 por 100 del promedio del precio del trigo entre 1859 y 1869 en Barcelona y el 9 por 100 del correspondiente a Jerez. 
tido, solicitaron que el arancel no fuera en ningún caso inferior a siete reales por fanega, lo que representaba entre un 12 ó un 13 por 100 de los precios del trigo en el litoral ${ }^{61}$.

Figuerola no estuvo dispuesto a aceptar ninguna modificación a su propuesta. Para él era una cuestión de gabinete y no deseaba transigir con los que él llamaba "los proveedores de la muerte". Consideraba que el arancel establecido era suficiente porque, como demostraba la experiencia histórica, en años normales no se produciría una inundación de trigo extranjero. Sin embargo, "la libertad cura los males de la carestía artificial creada por la prohibición"62. Por su parte, Echegaray afirmó que, siendo el actual seguro de contrabando de cuatro reales por fanega, no se podía establecer un arancel superior a los cinco reales sin que se perjudicase a los consumidores y se favoreciera a los "mercaderes del hambre"63.

Aunque Madoz y otros diputados propusieron posponer la decisión hasta que se recopilara una información más pormenorizada, la tradicional maniobra obstruccionista, el gobierno y su mayoría parlamentaria se negaron a transigir ante los representantes de los productores de trigo y sus aliados. Las enmiendas de éstos fueron rechazadas y las bases de la reforma arancelaria propuesta por Figuerola se aprobaron por una amplia mayoría, a pesar de la amenaza que para la estabilidad del nuevo régimen suponía la oposición de cerealistas e industriales ${ }^{64}$.

\section{Epílogo}

A partir del contraste de los precios del trigo de los mercados litorales con los datos y argumentos ofrecidos por productores e importadores, se puede concluir que, durante el período analizado, las ciudades del litoral podían disponer de una alternativa de abastecimiento en el exterior tan barata como la producción triguera del interior. El peligro de que una importación de trigo barato hiciese caer los precios en el litoral, sobre todo en ciertos momentos del año o en períodos de escasez, no era figurado sino que nacía de la existencia de una alternativa real. Ahora bien, la competencia del trigo foráneo no hubiera supuesto la total pérdida del mercado litoral para el trigo del interior. La importación de trigo ruso o norteafricano sólo resultaba

61 La propuesta del diputado Diego García, en DSCC, 27/06/1869, p. 3.229.

62 DSCC, $27 / 06 / 1869$, p. 3.236.

63 DSCC, $27 / 06 / 1869$, p. 3234.

64 García Barzanallana (1870), que desde 1849 se había mostrado partidario de instaurar un arancel a la importación de cereales, expresó su oposición al bajo derecho establecido porque habría de perjudicar notablemente a la producción española. 
rentable para los comerciantes andaluces o catalanes cuando el trigo del interior superaba un determinado umbral en los mercados del litoral. Este nivel de precios se alcanzó de forma casi constante desde 1854.

El debate público sobre la incidencia del prohibicionismo comenzó con la crisis de subsistencias de 1847, durante la cual se hizo evidente la dificultad para neutralizar los efectos de la escasez y la carestía. En este contexto, algunos grupos vinculados al comercio exterior ${ }^{65}$ llegaron a proponer la sustitución del prohibicionismo por una protección arancelaria capaz, tanto de preservar la producción nacional, como de reducir la escasez y la carestía en los años de malas cosechas. Esta alternativa se esbozó durante el debate de la reforma arancelaria de 1849, la primera en la que se contempló una tímida liberalización en las manufacturas de algodón, pero no se llegó a recoger entre sus disposiciones. Tampoco se incluyó en los proyectos fallidos de reforma arancelaria de 1855, 1856 y 1863. La resistencia a introducir el capítulo del trigo en las reformas arancelarias terminó por bloquear cualquier avance liberalizador significativo. En un régimen político que se sustentaba en una participación política muy restringida, el poder de la coalición prohibicionista resultó determinante.

Las consecuencias negativas del prohibicionismo quedaron al descubierto, de nuevo, durante la crisis de subsistencias de 1856 y 1857. El crecimiento de las exportaciones trigueras sin que las ciudades del litoral tuvieran opciones de importar de otros mercados alternativos y la restrictiva gestión del decreto de 1834, que regulaba la admisión de trigos foráneos, depararon una nueva situación de escasez y carestía con graves consecuencias sociales. El modelo que combinaba la libertad de exportación con la prohibición de importar facilitaba, sobre todo, la captación de unos beneficios extraordinarios a los que no había ánimo de renunciar, como muestra la presión ejercida para restablecer la prohibición de importar trigo en 1859.

La resistencia a la reforma nacía del miedo a los efectos de la supresión del prohibicionismo. El temor no derivaba tanto de una pérdida sustancial de los mercados litorales, como de la probable consolidación de unos precios más bajos. Únicamente en aquellos períodos en los que las exportaciones de trigo hubieran crecido de forma considerable, se habrían importado masivamente trigos foráneos más baratos para compensar la escasez en los mercados del litoral. En definitiva, a medio plazo, los mercados habrían tendido a estabilizarse y los beneficios extraordinarios se habrían reducido considerablemente. Este nuevo marco institucional habría forzado a los propietarios y labradores a incrementar sus beneficios por la vía del aumento

65 La firme crítica del prohibicionismo en el comercio de cereales que realizaron los comerciantes gaditanos era una pieza básica para alcanzar una liberalización más generalizada que les permitiera implantar su modelo económico: la ciudad abierta al comercio exterior gracias a la existencia de un puerto franco. 
de la productividad porque, independientemente de las condiciones ambientales, existía margen para ello en numerosas explotaciones deficientemente gestionadas ${ }^{66}$.

El restablecimiento de la prohibición en 1859, fruto de las presiones de la coalición prohibicionista (integrada por propietarios, labradores e industriales de la zona deficitaria más importante) mostró el carácter oligárquico del régimen isabelino y su incapacidad para afrontar reformas más profundas. De hecho, acabó perdiendo una parte de su soporte político por la decisión de los progresistas de abandonar las contiendas electorales (retraimiento) y de contribuir a la construcción de un nuevo régimen político. La repetición, por tercera vez, de la misma secuencia de hechos durante la crisis de subsistencias de 1866-1868 (exportaciones, escasez, carestía, protestas sociales, etc.), terminó por convertir la supresión del prohibicionismo en el comercio de trigo en un factor de movilización a favor del cambio político.

Tras la revolución de 1868, una vez establecido un nuevo régimen político sobre la base del sufragio universal masculino, los partidarios de abolir la prohibición constituyeron una amplia mayoría y llevaron a cabo la reforma arancelaria prometida, incluyendo cambios en el comercio de cereales y de productos manufacturados. En consecuencia, sólo la ampliación del sistema de representación política pudo terminar con un prohibicionismo nacido en circunstancias excepcionales durante los comienzos del régimen liberal.

\section{Bibliografía}

ARTAL I VIDAL, Francesc (2000): “El desarrollo del pensamiento proteccionista catalán en la segunda mitad del siglo XIX", en FUENTES QUINTANA, Enrique (dir.), Economía y economistas españoles. IV. La economía clásica, Barcelona, Galaxia Gutenberg y Círculo de Lectores, pp. 543-555.

BARQUÍN GIL, Rafael (1997): “Transporte y precio del trigo en el siglo XIX: creación y reordenación de un mercado nacional", Revista de Historia Económica, XV, 1, pp. 17-50.

—(1999): “El precio del trigo en España (1814-1883)", Historia Agraria, 17, pp. 177217.

—(2001): Precios del trigo e indices de consumo en España: 1765-1883, Burgos, Universidad de Burgos.

66 Lo reconocía un firme defensor del prohibicionismo y partidario de la introducción de los cambios técnicos en la producción agrícola, como Hidalgo de Tablada (1864), p. 250. En este sentido son pertinentes las apreciaciones de Llopis (2002) y Simpson (1997) respecto de las posibilidades de mejora de la agricultura española con otro marco institucional. 
BERNAL, Antonio Miguel (1979): La lucha por la tierra en la crisis del Antiguo Régimen, Madrid, Taurus.

CABRILLO RODRÍGUEZ, Francisco (2000): “Laureano Figuerola o el reformismo economista", en FUENTES QUINTANA, Enrique (dir.), Economía y economistas españoles. IV. La economía clásica, Barcelona, Galaxia Gutenberg y Círculo de Lectores, pp. 483-497.

CARO CANCELA, Diego, y RODWAY CHAMORRO, Carlos (2002): “Los precios del trigo en Jerez de la Frontera en el siglo XIX (1801-1895)", Revista de Historia de Jerez, 8, pp. 237-256.

COMÍN, Francisco, y VALLEJO, Rafael (2002): Alejandro Mon y Menéndez (1801-1882): Pensamiento y reforma de la Hacienda, Madrid, Ministerio de Hacienda, Instituto de Estudios Fiscales.

COSTAS COMESAÑA, Antón (1988): Apogeo del liberalismo en "La Gloriosa": la reforma económica en el Sexenio liberal (1868-1874), Madrid, Siglo XXI.

-(2000): "Industrialización y cuestión arancelaria en España. Reflexiones en torno al liberalismo de Laureano Figuerola", en FUENTES QUINTANA, Enrique (dir.), Economía y economistas españoles. IV. La economía clásica, Barcelona, Galaxia Gutenberg y Círculo de Lectores, pp. 459-482.

DURÁN, Nelson (1979): La Unión Liberal y la modernización de la España isabelina. Una convivencia frustrada, 1854-1868, Madrid, Akal.

FRADERA, Josep María (1987): Industria i mercat. Les bases comercials de la industria catalana moderna (1814-1845), Barcelona, Crítica.

GALLEGO, Domingo (2001): “Historia de un desarrollo pausado: integración mercantil y transformaciones productivas de la agricultura española (1800-1936)", en PUJOL, Josep; GONZÁLEZ DE MOLINA, Manuel; FERNÁNDEZ PRIETO, Lourenzo; GALLEGO, Domingo, y GARRABOU, Ramón, El pozo de todos los males. Sobre el atraso en la agricultura española contemporánea, Barcelona, Crítica, pp. 147-214.

-(2004):"La formación de los precios del trigo en España (1820-1869): el contexto internacional", Historia Agraria, 34, pp. 61-100.

-(2005)."La formación de los precios del trigo en España (1820-1869): el mercado interior «, Historia Agraria, 36, pp. 263-285.

GARCÍA BARZANALLANA, José (1870): La admisión de cereales extranjeros, Madrid, Imprenta de Berenguillo.

GARCÍA SANZ, Ángel (1985): “Crisis de la agricultura tradicional y revolución liberal (1800-1850)" en GARCÍA SANZ, Ángel, y GARRABOU, Ramón (eds.), Historia agraria de la España contemporánea. Cambio social y nuevas formas de propiedad (1800-1850), Barcelona, Crítica, 1985, pp. 7-99.

GARRABOU, Ramón (1980):"Un testimonio de la crisis de subsistencias de 1856-57: el expediente de la Dirección General de Comercio", Agricultura y Sociedad, 14, pp. 268-356. 
GARRABOU, Ramón, y SANZ FERNÁNDEZ, Jesús (1985): “Introducción. La agricultura española durante el siglo XIX: ¿inmovilismo o cambio?”, en GARRABOU, Ramón, y SANZ FERNÁNDEZ, Jesús (eds.), Historia agraria de la España contemporánea. Expansión y crisis (1850-1900), Barcelona, Crítica, pp. 7-191.

GARRABOU, Ramón; TELLO, Enric, y ROCA, Albert (1999): “Preus del blat i salaris agrícolas a Catalunya (1720-1936)", en GUTIÉRREZ, Miquel (coord.), La industrialización y el desarrollo económico de España. Homenaje al Dr. Jordi Nadal, Barcelona, Universidad de Barcelona, I, pp. 422-460.

GEHR (1985): "Los precios del trigo y de la cebada, 1874-1906" en GARRABOU, Ramón, y SANZ FERNÁNDEZ, Jesús, Historia agraria de la España contemporánea. Expansión y crisis (1850-1900), Barcelona, Crítica, pp. 321-368.

HIDALGO DE TABLADA, José (1864): Curso de economía rural española, Madrid, Imprenta de la Señora viuda e hijos de D. José Cuesta.

KIERNAN, Víctor G. (1970): La revolución de 1854 en España, Madrid, Aguilar.

KONDO, Agustín Y. (1990): La agricultura española del siglo XIX, Madrid, Nerea.

LEBÓN FERNÁNDEZ, Camilo, y SÁNCHEZ LISSEN, Rocío (2000): “Gabriel Rodríguez: un combativo economista liberal en el último tercio del siglo XIX español", en FUENTES QUINTANA, Enrique (dir.), Economía y economistas españoles. IV. La economía clásica, Barcelona, Galaxia Gutenberg y Círculo de Lectores, pp. 507-533.

LIDA, Clara E. (1972): Anarquismo y revolución en la España del siglo XIX, Madrid, Siglo XXI.

LLOPIS AGELÁN, Enrique (2002): “Otras caras menos amables de la agricultura española contemporánea", Historia Agraria, 28, pp. 179-198.

LLUCH, Ernest (1973): El pensament econòmic a Catalunya, 1760-1840: els orígens ideológics del proteccionisme i la presa de conciència de la burguesia catalana, Barcelona, Edicions 62.

MARTÍNEZ RUIZ, José Ignacio (2005): “El mercado internacional de cereales y harina, y el abastecimiento de la periferia española en el siglo XVIII: Cádiz, entre la regulación y el mercado", Investigaciones de Historia Económica, 1, pp. 45-79.

MONTAÑÉS, Enrique (2005): “La consolidación del prohibicionismo en el comercio del trigo (1820-1847)", en CARO CANCELA, Diego (ed.), El primer liberalismo en Andalucía (1808-1868). Política, economía y sociabilidad, Cádiz, Universidad de Cádiz, pp. 207-247.

MORENO LÁZARO, Javier (2003): “Fiscalidad y revueltas populares en Castilla y León durante el bienio progresista, 1854-1856", Historia Agraria, 31, pp. 111-139. PÉREZ MOREDA, Vicente (1997): “La población”, en FERNÁNDEZ GARCÍA, Antonio (coord.), Los fundamentos de la España liberal (1834-1900). Historia de España Menéndez Pidal, XXXIII, Madrid, Espasa-Calpe, pp. 53-98. 
PUJOL, Josep; GONZÁLEZ DE MOLINA, Manuel; FERNÁNDEZ PRIETO, Lourenzo; GALLEGO, Domingo, y GARRABOU, Ramón (2001): El pozo de todos los males. Sobre el atraso en la agricultura española contemporánea, Barcelona, Crítica.

SÁNCHEZ SUÁREZ, Alejandro (1990): Protecció, ordre i llibertat: el pensament i la política económica de la Comissió de Fábriques de Barcelona (1820-1840), Barcelona, Altafulla.

SÁNCHEZ ALBORNOZ, Nicolás (1963): Las crisis de subsistencias de España en el siglo XIX, Rosario, Instituto de Investigaciones Históricas.

—(1970): “El trasfondo económico de la Revolución”, en LIDA, Clara E., y ZAVALA, Iris R., La revolución de 1868. Historia, pensamiento, literatura, New York, Las Americas Publishing Company, pp. 64-79.

SÁNCHEZ LEÓN, Pablo (1999): Libertad económica versus pluralismo político: la movilización a favor del libre comercio en Inglaterra y en España, 1840-1849, Madrid, Instituto Universitario Ortega y Gasset.

SIMPSON, James (1997): La agricultura española (1765-1965): la larga siesta, Madrid, Alianza.

—(2002): "El pozo, y el debate sobre la agricultura española", Historia Agraria, 28, pp. 217-228.

VALLEJO POUSADA, Rafael (2001): Reforma tributaria y fiscalidad sobre la agricultura en la España liberal, 1845-1900, Zaragoza, Prensas Universitarias de Zaragoza. 